International Journal of Environment, Agriculture and Biotechnology
Vol-6, Issue-5; Sep-Oct, 2021
J Journal Home Page Available: https://ijeab.com/
Journal DOI: $10.22161 /$ ijeab

\title{
Status of Solid Wastes and its Management in the Coastal Environments of Sri Lanka
}

\author{
LY Hitige ${ }^{1}$, TMWRMB Samarakoon ${ }^{2}$
}

${ }^{1}$ Department of Civil Engineering, General Sir John Kotelawala Defence University, Sri Lanka.

${ }^{2}$ Senior Lecturer, Department of Civil Engineering, General Sir John Kotelawala Defence University, Sri Lanka.

Received: 06 Aug 2021; Received in revised form: 03 Sep 2021; Accepted: 12 Sep 2021; Available online: 20 Sep 2021

(C)2021 The Author(s). Published by Infogain Publication. This is an open access article under the CC BY license

(https://creativecommons.org/licenses/by/4.0/).

\begin{abstract}
The study was conducted to evaluate the status of solid wastes and waste management in the coastal environments of Sri Lanka. Fifteen coastal environments of Sri Lanka were selected as the sampling locations for the study. The research methodology comprised analyzing the types of solid wastes and the composition of each type of solid wastes in a unit area. The sources of solid wastes governing marine litter were identified. In addition, interviews were conducted with individuals in each sampling location and with five major organizations related to the coastal environment of Sri Lanka, to investigate the solid waste management methods existing in the coastal zone and their effectiveness. The study revealed that there was an average of $4.2 \mathrm{~kg}$ and 50 pieces of debris per a square meter of beach. The results of the study presented that tourist beaches away from the town limits show the highest density of solid wastes and coastal environments in river mouths show the next highest. Plastic was identified as the dominant material governing marine litter in coastal environments. The interviews indicated that the lack of infrastructure facilities in the country, inappropriate and illegal waste dumping, absence of proper waste management systems, and less awareness on this issue governs the accumulation of solid wastes in the coastal environments and end up as marine litter. The study concludes that there is a need for utilizing proper waste management in the coastal environments with the effective use of available infrastructure facilities. At the same time, the need of promoting plastic recycling and acknowledging the community regarding the impact of solid wastes on marine litter is much needed. The study introduces a mobile application as a communication application to enhance the effective waste management of solid wastes with the available facilities and to motivate the community to save the coastal ecosystems of Sri Lanka.
\end{abstract}

Keywords - Coastal environment, Marine litter, Mobile application, Plastic, Solid wastes

\section{INTRODUCTION}

Sri Lanka, the pearl of the Indian ocean is an island hallowed with plenty of natural resources. The ocean surrounding is one of the major assets comprise of attractive ecosystems with lots of endemic species including coral reefs and mangroves which, provide food and shelter for marine lives as well as food and livelihoods for human beings. Recently, Marine litter has become a burning issue threatening marine lives and human populations in the world.

A study conducted on selecting 192 countries which include residents that border the Atlantic ocean, Pacific ocean, Indian ocean, Black Sea, and Mediterranean sea revealed that Sri Lanka is $5^{\text {th }}$ out of the top twenty countries polluting the ocean (J. Jambeck et al., 2015). Vital economic sectors such as tourism, fishing industry, and recreational activities are related to the coastal ecosystems in the country. On the other hand with the growth of populations, most of the beaches have become residential. It is obvious, the marine litter which accumulates in the ocean from various sources gets transport long distances in the sea before they get settled in the sea due to winds and other ocean currents. As a result, it becomes a complex task to identify the relevant source of marine litter found in the ocean. But it has been identified that $80 \%$ of marine litter is getting generated from land-based sources (OSPAR UNEP, 2009). 
A study on water quality of the coastal belt, western province, Sri Lanka, revealed the organic and inorganic pollution in all the sampling locations. It demarcated that ammonia concentration and dissolved oxygen levels are below the maximum permissible limits while $\mathrm{pH}$ value within the acceptable limit and biochemical oxygen demand was higher than the allowed threshold limit. It realizes that the wastes added to the ocean contribute to lowering the quality of seawater (Jinadasa, 2014).

Waste Management Authority, 2016, estimated municipal waste generation in Sri Lanka is about 6500 to $7000 \mathrm{Mt}$ /day and collection is $3500 \mathrm{Mt} /$ day which is $50 \%$ of the generated. The other 50 percent is dumped or discarded into the nearest environment. As a result of these situations, a large amount of land-based solid wastes enter the coastal and marine environments (JICA, 2016).

Solid wastes in the coastal environment significantly contribute to marine pollution. Long-term deposition of wastes in the ocean for many decades causes harm to the ecological and economical value along with the biodiversity (Gregory, 2009). As a developing country, Sri Lanka faces challenges related to environmental management due to poorly developed waste management infrastructure and extreme weather events (Jang et al., 2018). Hence, marine litter has become a vital issue related to solid waste management in the coastal environments of Sri Lanka. There are scattered numbers of government agencies responsible for solid waste management. Thus, the effectiveness of marine solid waste management is still questionable.

Jinadasa (2014) revealed the need for awareness programs about coastal pollution should be conducted among the coastal communities including fishermen and school children. The improvement of public health to increase sanitation such as providing facilities for people in the vicinity of the coastal areas should be implemented as it will have an impact on the aquatic health of the marine environment. He recommends that proper monitoring programs should be initiated for the identification of water pollutant sources, which discharge pollutants into the marine waters directly or indirectly and actions should be taken to prevent further damage to the marine environment.

The study aims to minimize the addition of solid wastes into the ocean. Therefore, the objectives of the study were, to identify the types of solid wastes and their composition in the coastal environments of Sri Lanka, to evaluate the sources of solid wastes in the marine environments, to identify the existing solid waste management methods currently adopted and their effectiveness, and finally to propose a solution for the issues related with the solid waste management in coastal environments.

\section{MATERIALS AND METHOD}

\subsection{Coastal Zone of Sri Lanka}

Sri Lanka lies in the bay of Bengal between $5^{\circ} 55^{\prime \prime}$ and $9^{\circ} 51^{\prime \prime}$ latitudes north and between $79^{\circ} 41^{\prime \prime}$ and $81^{\circ} 53^{\prime \prime}$ south east longitude near the equator with an extent of the land area of $65610 \mathrm{~km} 2$. Figure 1 depicts the coastal belt of Sri Lanka which is $1,620 \mathrm{~km}$ long divided into eight coastal sections centering the Piduruthalagala mountain range (Silva, Katupotha, Amarasinghe, Manthrithilake, \& Ariyaratna, 2013).

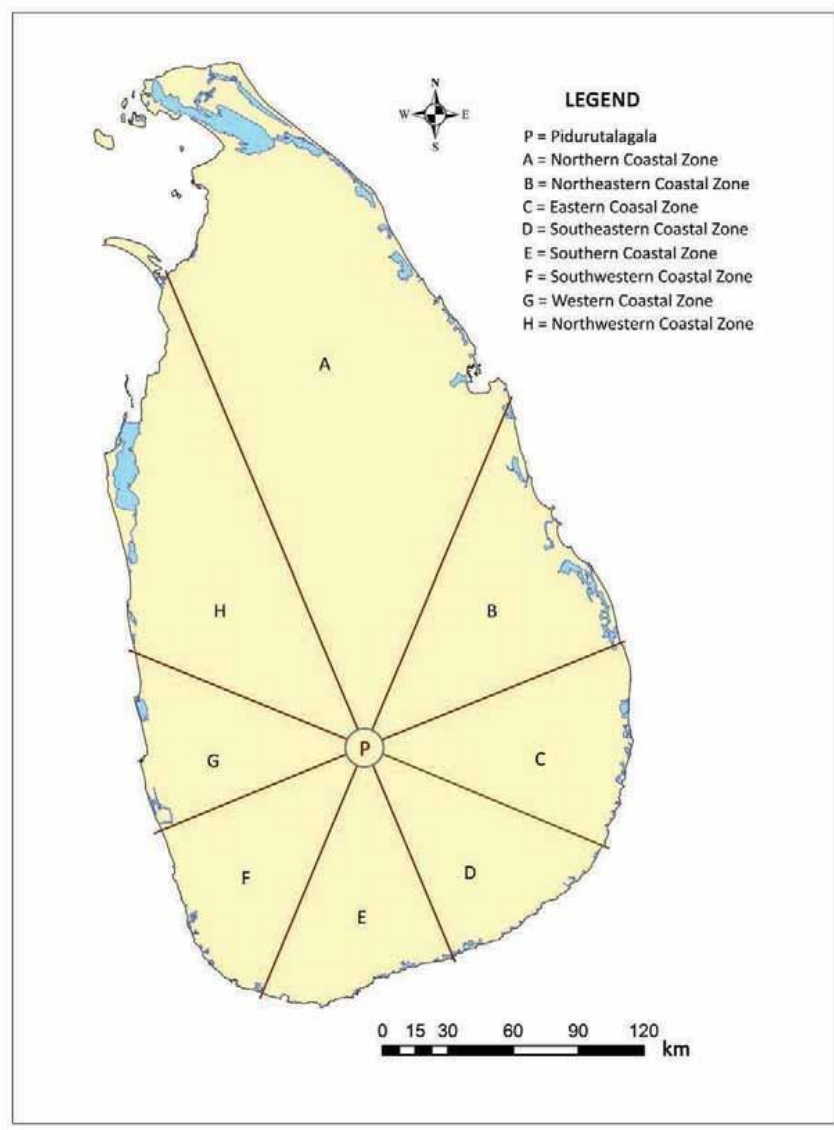

Fig. 1 - Coastal zone of Sri Lanka divided into eight coastal sections (Silva et al., 2013).

Sri Lanka owes an extent of $517,000 \mathrm{~km}^{2}$ of the ocean from the declaration of an exclusive economic zone. The coast conservation (amendment) act, No. 49 of 2011 defines the "Coastal zone" as "The area lying within a limit of $300 \mathrm{~m}$ landward of the mean high water level and a limit of $2 \mathrm{~km}$ seaward of the mean low water level. In the case of a water body connected to the sea either permanently or periodically, the land boundary extends $2 \mathrm{~km}$ measured perpendicular to the straight baseline drawn between the natural entrance points. Thereof and includes the waters of such rivers, streams, and lagoons or any other body of water so connected to the sea" (Parliament of the Democratic 
Socialist Republic of Sri Lanka Coast Conservation (Amendment) Act. No. 49 of 2011, 2009).

Accordingly, the coastal zone of Sri Lanka comprises $24 \%$ of the total land area of the country under 74 divisional secretariat divisions. Approximately, the coastal population is around 18.8 million which represents one-fourth of the total population of the country. (Koralagama, 2008) There are numerous shipping and fishery harbors, ports, salterns, and tourist hotels located along the coastal belt while most of the beaches have become residential due to high population. Significantly, the inhabitants of the coastal environments are mostly low-income families in the country with deprived standards of existing.

\subsection{Data Collection}

The study was mainly conducted by visiting selected beaches of Sri Lanka. Table 3 shown below depicts the sampling locations selected for the study, differed from each other including urbanized beaches near cities, remote beaches which are isolated from human interfere, tourist beaches, and marine environments near river mouths. A team comprised of 4 trained members were involved and the data were collected from one location per day. The data collection was begun in July 2019. In each of the coastal environments, a land area was randomly selected and surface area was measured. The solid wastes in the selected area were categorized following the type of material. The weight of each type of solid wastes was measured. At the same time, the number of items of each type of material was counted. Then the composition of solid wastes in each of the coastal environments per unit area was calculated in terms of weight and number of items. Simultaneously, sources of marine solid wastes were identified and the solid waste management method implied in each of the beaches was identified. A vocal interview was conducted with a selected responsible person in each of the marine environments to gather data on waste collection and frequency of collection.

Five major government authorities related to the coastal environments of Sri Lanka were interviewed with a questionnaire to collect information on the effectiveness of the existing solid waste management methods in the coastal zone of Sri Lanka and their suggestions to overcome this marine debris issue. The organizations interviewed were the Central Environmental Authority (CEA), Marine Environmental Protection Authority (MEPA), Moratuwa Municipal Council (MMC), Coast Conservation \& Coastal Resource Management Department (CC\&CRMD) and United Nations Development Program (UNDP).

From the findings of the study, a mobile application was introduced as a solution to the accumulation of solid wastes in the beaches through a communication system. It was developed using Android Studio and java coding using firebase as the database. The coding can be changed and further improvements to the application can be done.

\section{RESULTS AND DISCUSSION}

\subsection{Sources of Solid wastes}

Solid wastes in the coastal environments were comprised of domestic wastes, solid wastes from recreational activities, tourism and other industry-based wastes, smoking-related wastes, medical waste, etc. In the study, they were classified according to the type of material. The main types of solid wastes identified were categorized as plastic, glass, metal, wood, paper and polythene, and others. Solid wastes from the inland of the country, accumulated in the coastal zone came via rivers, streams, and other waterways were observed in the sampling locations. In addition, solid wastes with foreign labels and fishing vessels floated with sea waves due to winds were identified in the beaches as litter. Solid wastes scattered in the beaches due to tourism, recreational activities, and coastal-based industries were most commonly noted in the visited coastal environments. Solid wastes directly dumped into the beaches were commonly observed in the visited residential beaches. It is manifest that the sources of solid wastes in the coastal environment can be identified as land-based, coastal based and sea-based sources. Wickramaarachchi et al (2010), revealed that litter from the inland-based sources mostly governs on marine debris.

\subsection{Composition of Solid Wastes}

The study revealed that there was an average of $4.2 \mathrm{~kg}$ and 50 pieces of debris per square meter of a beach. Plastic was observed as the dominant material in marine solid wastes where $48 \%$ concerning weight and $41 \%$ concerning the number of items per unit area were observed in the

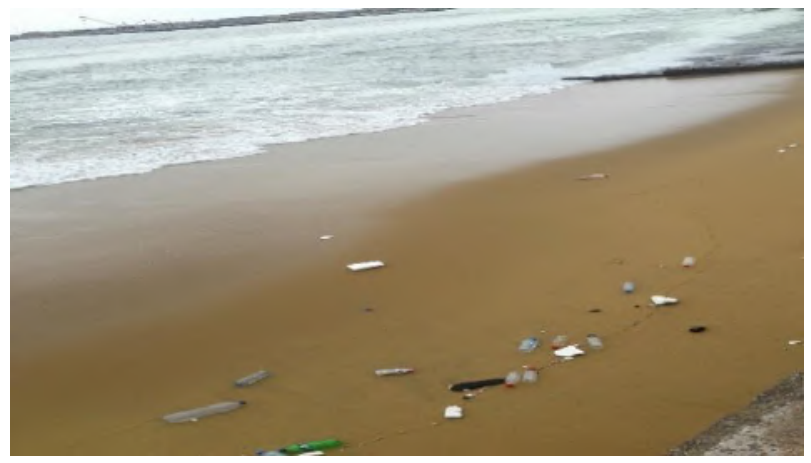

Fig. 2 -Solid wastes scattered in the coastal belt, Galle Face, Colombo

sampling locations. Table 1 shows the composition of each type of solid wastes in the overall sampling locations.

The analysis of the composition of solid wastes in the sampling locations are illustrated in Table 2. Plastic is the 
leading material in solid wastes in most of the beaches concerning weight, except in Galle fort, Wennappuwa, Negombo, and Ging river valley where glass is the highest due to its high density. But concerning the number of items per unit area, plastic was recorded the highest in all the sampling locations in the study.
Table 1 -Overall percentage of each type of solid wastes collected in sampling locations in a unit area

\begin{tabular}{|l|c|c|}
\hline Material & Weight & Number \\
\hline Plastic & $48 \%$ & $41 \%$ \\
\hline Glass & $39 \%$ & $8 \%$ \\
\hline Metals & $9 \%$ & $10 \%$ \\
\hline Woods & $1 \%$ & $3 \%$ \\
\hline Paper and Polythene & $1 \%$ & $19 \%$ \\
\hline Others & $2 \%$ & $20 \%$ \\
\hline
\end{tabular}

Table. 2 - Composition of each type of solid waste in the sampling locations

\begin{tabular}{|c|c|c|c|c|c|c|c|c|c|c|c|c|}
\hline \multirow[b]{2}{*}{ Coastal Environment } & \multicolumn{6}{|c|}{ Weigh per unit area } & \multicolumn{6}{|c|}{ Parts per unit area } \\
\hline & 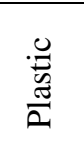 & $\frac{\tilde{E}}{0}$ & 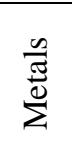 & $\begin{array}{l}0 \\
8 \\
8 \\
3\end{array}$ & 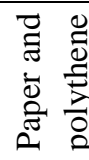 & $\begin{array}{l}\frac{\infty}{\Delta} \\
\stackrel{\Xi}{0}\end{array}$ & 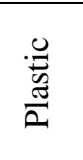 & $\frac{\tilde{E}}{0}$ & $\frac{\infty}{\sum}$ & $\begin{array}{l}0 \\
8 \\
8 \\
3\end{array}$ & 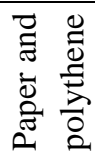 & 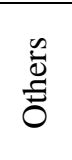 \\
\hline Colombo Galle face & $65 \%$ & $26 \%$ & $5 \%$ & $0 \%$ & $1 \%$ & $3 \%$ & $48 \%$ & $5 \%$ & $5 \%$ & $0 \%$ & $19 \%$ & $24 \%$ \\
\hline Galle Fort & $20 \%$ & $79 \%$ & $0 \%$ & $0 \%$ & $0 \%$ & $0 \%$ & $40 \%$ & $40 \%$ & $0 \%$ & $0 \%$ & $20 \%$ & $0 \%$ \\
\hline Jungle beach & $50 \%$ & $39 \%$ & $7 \%$ & $1 \%$ & $1 \%$ & $2 \%$ & $42 \%$ & $8 \%$ & $7 \%$ & $4 \%$ & $19 \%$ & $19 \%$ \\
\hline Mount Lavinia beach & $50 \%$ & $40 \%$ & $6 \%$ & $1 \%$ & $1 \%$ & $4 \%$ & $42 \%$ & $8 \%$ & $6 \%$ & $4 \%$ & $11 \%$ & $30 \%$ \\
\hline Ratmalana beach & $47 \%$ & $40 \%$ & $9 \%$ & $1 \%$ & $1 \%$ & $2 \%$ & $43 \%$ & $9 \%$ & $11 \%$ & $5 \%$ & $16 \%$ & $16 \%$ \\
\hline Galle fishery harbor & $48 \%$ & $37 \%$ & $10 \%$ & $0 \%$ & $1 \%$ & $4 \%$ & $37 \%$ & $7 \%$ & $10 \%$ & $0 \%$ & $18 \%$ & $28 \%$ \\
\hline Wennappuwa beach & $40 \%$ & $46 \%$ & $9 \%$ & $0 \%$ & $2 \%$ & $3 \%$ & $29 \%$ & $8 \%$ & $8 \%$ & $0 \%$ & $31 \%$ & $23 \%$ \\
\hline Negombo beach & $37 \%$ & $49 \%$ & $10 \%$ & $0 \%$ & $1 \%$ & $4 \%$ & $30 \%$ & $10 \%$ & $10 \%$ & $0 \%$ & $20 \%$ & $30 \%$ \\
\hline Kahawa beach & $49 \%$ & $42 \%$ & $6 \%$ & $0 \%$ & $0 \%$ & $3 \%$ & $48 \%$ & $10 \%$ & $7 \%$ & $0 \%$ & $7 \%$ & $28 \%$ \\
\hline Akurala beach & $40 \%$ & $37 \%$ & $20 \%$ & $0 \%$ & $1 \%$ & $3 \%$ & $33 \%$ & $8 \%$ & $21 \%$ & $0 \%$ & $15 \%$ & $23 \%$ \\
\hline Balapitiya beach & $45 \%$ & $39 \%$ & $13 \%$ & $0 \%$ & $2 \%$ & $1 \%$ & $40 \%$ & $9 \%$ & $14 \%$ & $0 \%$ & $31 \%$ & $6 \%$ \\
\hline Moda river mouth valley & $79 \%$ & $12 \%$ & $5 \%$ & $2 \%$ & $2 \%$ & $1 \%$ & $57 \%$ & $2 \%$ & $4 \%$ & $4 \%$ & $28 \%$ & $4 \%$ \\
\hline Ging river mouth valley & $25 \%$ & $60 \%$ & $12 \%$ & $1 \%$ & $1 \%$ & $1 \%$ & $27 \%$ & $16 \%$ & $16 \%$ & $5 \%$ & $22 \%$ & $14 \%$ \\
\hline Kalu river mouth valley & $61 \%$ & $21 \%$ & $13 \%$ & $2 \%$ & $1 \%$ & $2 \%$ & $50 \%$ & $4 \%$ & $13 \%$ & $7 \%$ & $13 \%$ & $13 \%$ \\
\hline Kelani river mouth valley & $52 \%$ & $35 \%$ & $9 \%$ & $1 \%$ & $1 \%$ & $3 \%$ & $43 \%$ & $7 \%$ & $9 \%$ & $4 \%$ & $16 \%$ & $21 \%$ \\
\hline
\end{tabular}

The highest density of solid wastes per unit area $(8.25$ $\mathrm{kg} / \mathrm{m}^{2}$, where 98 items $/ \mathrm{m}^{2}$ ) was observed in Jungle beach which is a famous tourist beach located in a remote area away from the main city of Galle. The least was recorded in Galle fort $\left(1.05 \mathrm{~kg} / \mathrm{m}^{2}\right.$, where 5 parts $\left./ \mathrm{m}^{2}\right)$ which is also one of the famous tourist beaches in the central town of Galle. Figure 3 shows the comparison of total solid wastes in terms of weights and parts observed in a unit area in each of the sampling locations. Mount Lavinia beach, one of the famous tourist beaches away from the capital city of Sri Lanka shows the next highest percentage of solid wastes. 


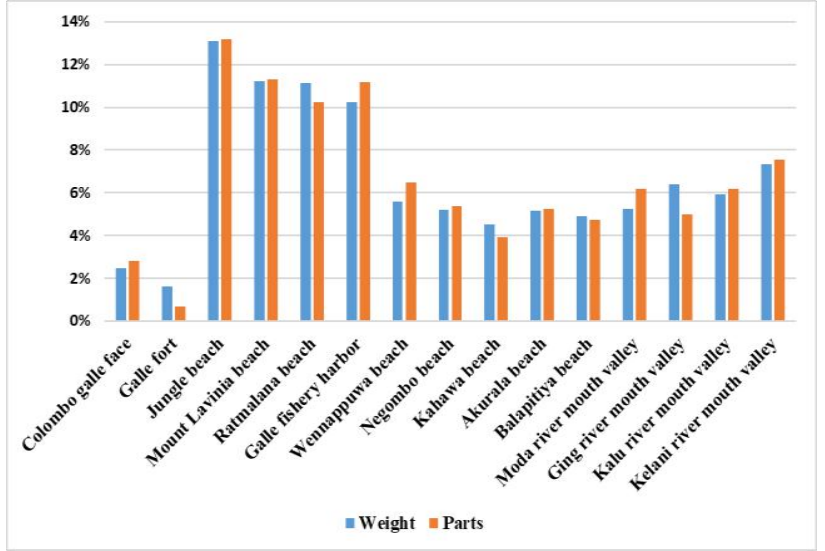

Fig. 3 - Comparison of solid wastes per unit area in each sampling location concerning weight and number of items.

Ratmalana beach is a highly residential beach with more than 50 families living in the coastal belt. Galle fishery harbor, one of the eminent centers for the fishing industry in the southern province too shows a high percentage of solid wastes when compared to others. It is vital that apart from the tourist beaches the next highest composition of solid wastes is depicted in the coastal environments near river mouths. It is prominent that most urbanized Colombo Galle Face beach and the Galle Fort beach which are highly populated with higher densities of population depict the least percentage of solid wastes per unit area. The waste generated is collected systematically with proper waste management on these beaches.

In the study, the data were collected once in a single day from each location. Hence, the composition of solid wastes obtained is an average value with the change of daily attraction of tourists and coastal-based industries. In addition, when counting the number of items from each type of material, the size of the parts was not taken into account and the microplastics deposited in the beach were neglected. Results obtained in the international coastal cleanup programs conducted in Sri Lanka in some of the selected beaches from 2008 to 2013 too reveal that $22.68 \%$ of plastic bags, $14.35 \%$ paper bags, $10.97 \%$ plastic bottles, $5.77 \%$ lids, and $5.61 \%$ food wraps have observed. Also, it has been investigated that $74.93 \%$ of recreational activities were likely to contribute to the accumulation of solid wastes in marine environments (Gunasekara, Priyadarshana, \& Ranasinghe, 2013).

A study on assessment of marine debris selecting 22 beaches along the coastal belt of Sri Lanka depicts an average of 4.1 large $(>25 \mathrm{~mm})$ and 158 small $(5-25 \mathrm{~mm})$ pieces of debris have amassed per square meter of beach and $93 \%$ of the total waste collected represent plastic in the debris. Further, the author reveals that the beaches near river mouths and tourist beaches have a greater debris accumulation. Also, the study depicts that the monitoring of marine litter will find the pathway for the possible management of solid wastes in the coastal environments (Yong Chang Jang, R R M K P Ranatunga, \& Kyung Shin Kim, 2011).

\subsection{Current Status of Solid Waste Management in the Coastal Environments.}

From the beach visits of the sampling locations the existing solid waste management methods which have been adopted in coastal environments were able to identify. In Colombo Galle Face and Galle Fort beaches, separated garbage collectors were available. Wind resistive solid waste collector was observed in Mount Lavinia beach while awareness notice boards were available on a few of the beaches. A management method for solid wastes directly entering the ocean via waterways was absent in the visited river mouths.

Table 3 illustrates the summary of the data gathered from the beach site visits and the oral interviews done with the people in the vicinity of each sampling location regarding the existing solid waste management practices adopted and their progress. Conveniently, the proper disposal of solid waste is conducted in the marine environments located in the urbanized cities while proper maintenance of solid waste is absent in the other beaches due to a lack of infrastructure facilities. The absence of a systematic collection of the generated solid wastes finally results in the accumulation of solid wastes over years and finally becomes marine debris.

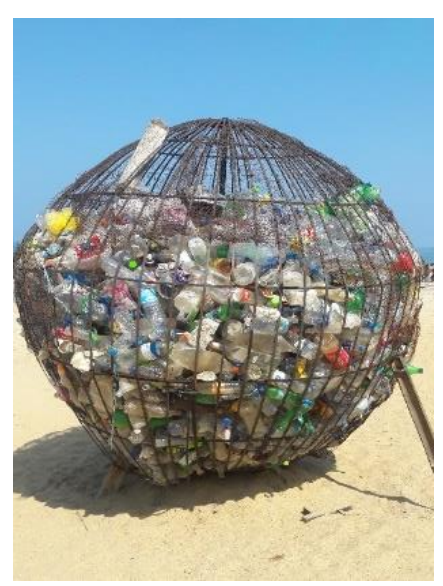

Fig. 4 - Wind resistive waste collector in Mount Lavinia 
Table 3 -Summary of solid waste management in the sampling locations

\begin{tabular}{|c|c|c|c|}
\hline $\begin{array}{l}\text { Sampling } \\
\text { location in } \\
\text { the coastal } \\
\text { area. }\end{array}$ & $\begin{array}{l}\text { Nature of } \\
\text { the location }\end{array}$ & $\begin{array}{l}\text { Solid waste } \\
\text { management } \\
\text { method } \\
\text { adopted and } \\
\text { observations }\end{array}$ & $\begin{array}{l}\text { Frequenc } \\
\text { y of solid } \\
\text { waste } \\
\text { collectio } \\
n\end{array}$ \\
\hline $\begin{array}{l}\text { Colombo } \\
\text { Galle Face }\end{array}$ & $\begin{array}{l}\text { Tourism } \\
\text { and } \\
\text { Commercia } \\
1 \text { activities/ } \\
\text { Urbanized }\end{array}$ & $\begin{array}{l}\text { Separated solid } \\
\text { wastes } \\
\text { collection and } \\
\text { regular } \\
\text { removal. }\end{array}$ & Daily \\
\hline Galle Fort & $\begin{array}{l}\text { Tourism } \\
\text { and } \\
\text { Commercia } \\
1 \text { activities/ } \\
\text { Urbanized }\end{array}$ & $\begin{array}{l}\text { Separated solid } \\
\text { wastes } \\
\text { collection and } \\
\text { regular } \\
\text { removal }\end{array}$ & Daily \\
\hline $\begin{array}{l}\text { Jungle } \\
\text { beach }\end{array}$ & $\begin{array}{l}\text { Tourism/ } \\
\text { Remote }\end{array}$ & $\begin{array}{l}\text { None. Directly } \\
\text { dumped solid } \\
\text { wastes. }\end{array}$ & $\begin{array}{l}\text { More } \\
\text { than six } \\
\text { months }\end{array}$ \\
\hline $\begin{array}{l}\text { Mount } \\
\text { Lavinia }\end{array}$ & $\begin{array}{l}\text { Tourism / } \\
\text { Urbanized } \\
\text { and } \\
\text { residential }\end{array}$ & $\begin{array}{l}\text { Metal garbage } \\
\text { collectors } \\
\text { present and } \\
\text { nonsystematic } \\
\text { garbage } \\
\text { removal. }\end{array}$ & $\begin{array}{l}\text { Weekly/ } \\
\text { Monthly }\end{array}$ \\
\hline Ratmalana & $\begin{array}{l}\text { Remote / } \\
\text { Residential }\end{array}$ & $\begin{array}{l}\text { None. Directly } \\
\text { dumped solid } \\
\text { wastes for a } \\
\text { prolonged } \\
\text { duration of } \\
\text { time. }\end{array}$ & $\begin{array}{l}\text { More } \\
\text { than } 6 \\
\text { month }\end{array}$ \\
\hline $\begin{array}{l}\text { Galle } \\
\text { fishery } \\
\text { harbor }\end{array}$ & $\begin{array}{l}\text { Commercia } \\
\text { 1/ } \\
\text { Urbanized }\end{array}$ & $\begin{array}{l}\text { None. Directly } \\
\text { dumped solid } \\
\text { wastes for a } \\
\text { prolonged } \\
\text { duration of } \\
\text { time. }\end{array}$ & $\begin{array}{l}\text { More } \\
\text { than a } \\
\text { year }\end{array}$ \\
\hline Wennappu & Tourism & $\begin{array}{l}\text { Nonsystematic } \\
\text { garbage } \\
\text { collection }\end{array}$ & Monthly \\
\hline Negombo & Tourism & $\begin{array}{l}\text { Nonsystematic } \\
\text { garbage } \\
\text { collection }\end{array}$ & Monthly \\
\hline Kahawa & $\begin{array}{l}\text { Remote / } \\
\text { No human } \\
\text { interfere }\end{array}$ & $\begin{array}{l}\text { None, } \\
\text { Scattered } \\
\text { wastes }\end{array}$ & None \\
\hline
\end{tabular}

\begin{tabular}{|l|l|l|l|} 
Akurala & $\begin{array}{l}\text { Remote / } \\
\text { No human } \\
\text { interfere }\end{array}$ & $\begin{array}{l}\text { None, } \\
\text { Scattered } \\
\text { wastes }\end{array}$ & None \\
\hline Balapitiya & $\begin{array}{l}\text { Remote / } \\
\text { No human } \\
\text { interfere }\end{array}$ & $\begin{array}{l}\text { None, } \\
\text { Scattered } \\
\text { wastes }\end{array}$ & None \\
\hline $\begin{array}{l}\text { Moda river } \\
\text { mouth } \\
\text { valley }\end{array}$ & Urbanized & $\begin{array}{l}\text { None, Solid } \\
\text { wastes directly } \\
\text { off to the } \\
\text { ocean }\end{array}$ & None \\
\hline $\begin{array}{l}\text { Ging river } \\
\text { mouth } \\
\text { valley }\end{array}$ & Urbanized & $\begin{array}{l}\text { None, } \\
\text { Scattered } \\
\text { wastes in the } \\
\text { valley }\end{array}$ & None \\
\hline $\begin{array}{l}\text { Kalu river } \\
\text { mouth } \\
\text { valley }\end{array}$ & Urbanized & None. & $\begin{array}{l}\text { No exact } \\
\text { duration }\end{array}$ \\
\hline $\begin{array}{l}\text { Kelani } \\
\text { river mouth } \\
\text { valley }\end{array}$ & Urbanized & None. & $\begin{array}{l}\text { No exact } \\
\text { duration }\end{array}$ \\
\hline
\end{tabular}

\subsection{Effectiveness of the Marine Solid Waste Management Methods}

The interviews with the five main authorities related to the coastal environment reveal that inappropriate, illegal waste dumping and the absence of proper waste management systems cause marine debris. When regard to plastic waste management techniques in Sri Lanka, the central environment authority revealed that still, we do not have a formal procedure in using available techniques and apply them for waste management. The following were the responses from the governing authorities for the reasons behind the addition of solid wastes into the Ocean in Sri Lanka. Absence of proper waste collection and disposal system, lack of proper technology transferring procedures, lack of public awareness, poor implementation of regulatory mechanisms, lack of collecting centers for plastic waste management, lack of enough rules and regulations and poor application of existing rules.

The five authorities suggested proposals to use the $3 R$ concept, starting with reduce, then reuse, and finally recycle to overcome the threat of plastic as marine litter which governs highest in marine solid wastes. Mainly, to reduce the usage of plastic and polythene bags, using alternatives such as cloth bags, increasing the price of plastic, implementation of laws \& regulations to plastic usage was suggested. Promoting the use of plastic bags repeatedly, organizing eco fairs in every local authority, introducing reusable plastic \& establish collecting centers, and 
awareness was suggested to promote reuse. Use of selected yards \& produce small items, placing of recycling centers island-wide, implementation of recycling plants \& centers, incentives for debris collectors were suggested to promote recycling of solid wastes. Further, the need of promoting new inventions as depicted in figure 5 and apply them practically was suggested.

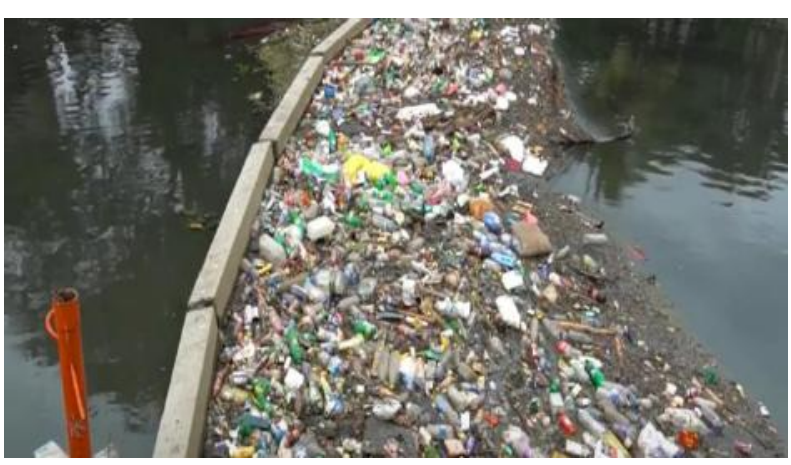

Fig. 5 -Proposed garbage trappers to prevent the entering of solid waste into the ocean through waterways.

\subsection{A solution to manage solid wastes in the coastal environments of Sri Lanka}

It was prominent that apart from the coastal environments in the town limits of the country, solid wastes are accumulated over years in the coastal environments out of towns. It is obvious that due to lack of infrastructure facilities the collection of solid wastes for disposal is not done systematically. The ineffective management of available infrastructure facilities and lack of communication has resulted in it. Therefore, the study introduces a mobile application to track the locations of solid wastes in the coastal zone of Sri Lanka and engage the relevant authorities to collect the wastes without letting them become marine debris.

J. R. Jambeck and Johnsen (2015) introduced a global scale mobile application "Marine Debris Tracker" to track and monitor the global scale marine litter using an application. More than 400,000 items have been tracked with plastic becoming the prominent type of litter polluting the ocean. "MarPol Tracker" which was introduced in the study was targeted to use as a communicating application to use in managing the solid wastes which causes marine debris in Sri Lanka.

The introduced application can be installed on android mobile phones and it was named "MarPol Tracker" which meant Marine Pollutant Tracker. Anyone with the application can upload a photo of a polluted coastal environment with a caption. A google map of Sri Lanka allows the user to mark up the location and it is marked in the map in red color as a critical location. Then a notification is sent to all the users with the application regarding the polluted area. So beach clean-up organizers and the relevant authorities can notify the polluted locations and can engage the available infrastructure facilities effectively to remove the solid wastes from relevant locations.

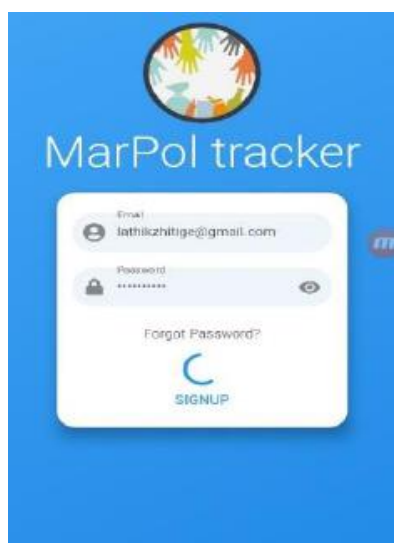

Fig. 6 - The main interface of the mobile application

Figure 6 illustrates the main interface to the login of the application. The map interface was taken from google maps. Figure 7 shows the interface available to input the data.

\section{MarPol tracker - ADD POST $=>$ Details}

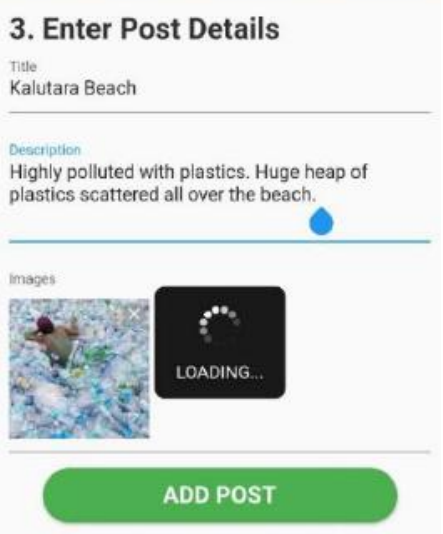

Fig. 7 - Interface to enter the location with a comment and add a photo.

After clearing the polluted environment the application allows uploading a new photo of the cleaned location with a comment. Simultaneously, the location marked previously in red turns to green in color and a notification is sent to all the users mentioning that the location was cleared. This application is a human controlling application and wise use of it is expected. It is mainly a communication application and also ii aware the community even in the inland of the country regarding the marine litter. Also, it can be 
mentioned as a motivational application because it motivates to turn the critical locations depicted in red, into the green color.

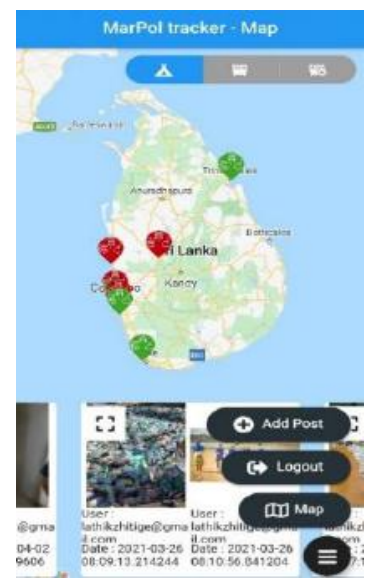

Fig. 8-Depicting the polluted locations in red and cleared locations with green.

The application can be further improved to make use not only for marine solid wastes, but also for solid waste management of the entire country.

\section{CONCLUSION}

The research elaborates regarding the sources of marine solid wastes which were categorized as sea-based, coastal based and land-based. The results of the analysis showed that the highest percentage of solid wastes records from tourist beaches away from the town limits and the next highest from coastal environments near the river mouths, and the least from beaches in the town. As a developing country, due to lack of resources the solid waste management has become non-systematic. Also, the paper proves that plastic governs marine pollution and acknowledges the needed authorities and community.

This paper presents the current situation of solid waste management with lacking infrastructure facilities in the country. The concern of governing authorities will pay attention in this regard and their suggestions will be implemented from the analysis of the research. Implying $3 \mathrm{R}$ principles for plastic recycling as suggested by the authorities related to coastal environments will be advantageous for future generations of the country. The introduced mobile application can be used as a communication application in the effective management of solid wastes with the available resources and can be used to aware the community. It is also a motivational application that can minimize marine debris.

This paper has analyzed only a few of the coastal locations in the country and the analysis has been done on a random day of the year. Analysis of marine litter following the seasons of the year considering the populations need to be implemented in the future studies.

\section{ACKNOWLEDGEMENTS}

The authors wish to thank the officials of the Central Environmental Authority, Marine Environmental Protection Authority, Moratuwa Municipal Council, Coast Conservation \& Coastal Resource Management Department and United Nations Development Program.

\section{REFERENCES}

[1] Gregory, M. R. (2009). Environmental implications of plastic debris in marine settings- entanglement, ingestion, smothering, hangers-on, hitch-hiking and alien invasions. Philosophical Transactions of the Royal Society B: Biological Sciences, 364(1526), 2013-2025. https://doi.org/10.1098/rstb.2008.0265

[2] Gunasekara, A. J. ., Priyadarshana, R. ., \& Ranasinghe, T. . (2013). Status of marine debris accumulated in coastal areas of Sri Lanka, (758), 758.

[3] Jambeck, J., Geyer, R., Wilcox, C., Siegler, T. R., Perryman, M., Andrady, A., ... Law, K. L. (2015). the Ocean: the Ocean : Marine Pollution, 347(6223), 768-. Retrieved from https://science.sciencemag.org/CONTENT/347/6223/768.ab stract

[4] Jambeck, J. R., Engineering, C., Johnsen, K., \& Engineering, C. (2015). Marine Debris Tracker : Citizen-based Litter and Marine Debris Data Collection and Mapping.

[5] Jang, Y. C., Ranatunga, R. R. M. K. P., Mok, J. Y., Kim, K. S., Hong, S. Y., Choi, Y. R., \& Gunasekara, A. J. M. (2018). Composition and abundance of marine debris stranded on the beaches of Sri Lanka: Results from the first island-wide survey. Marine Pollution Bulletin, 128(July 2017), 126-131. https://doi.org/10.1016/j.marpolbul.2018.01.018

[6] JICA. (2016). Data Collection Survey on Solid Waste Management in Democratic Socialist Republic of Sri Lanka Final Report Democratic Socialist Republic of Sri Lanka Japan International Cooperation Agency (JICA) Ten (10) Priority Local Authorities, (February), 22. Retrieved from http://open_jicareport.jica.go.jp/pdf/12250213.pdf

[7] Jinadasa, K. B. S. N. (2014). Water Pollution in Selected Coastal Areas in Western Province, Sri Lanka: A Baseline Survey Water Pollution in Selected Coastal Areas in Western Province, Sri Lanka: A Baseline Survey, (December). https://doi.org/10.4038/jepsl.v3i2.7843

[8] Koralagama, D. (2008). Community Perception Towards a Set Back Area : a Case Study in Galle District, Sri Lanka. IIFET 2008 Vietnam Proceedings, 2, 1-11.

[9] OSPAR UNEP. (2009). Marine litter.

[10] Parliament of the Democratic Socialist Republic of Sri Lanka Coast Conservation (Amendment) Act. No. 49 of 2011, Distribution $\S(2009)$.

[11] Silva, E. I. L., Katupotha, J., Amarasinghe, O., Manthrithilake, H., \& Ariyaratna, R. (2013). Lagoons of Sri 
Lanka: from the origins to the present. Lagoons of Sri Lanka: From the Origins to the Present, (January). https://doi.org/10.5337/2013.215

[12] Wickramaarachchi, N., Aquatic, N., Agency, D., Amarathunga, D., Aquatic, N., Agency, D., ... Agency, D. (2010). Assessment of Marine Litter in Coastal and Marine Environment of Western and Southern Coast of Sri Lanka in relation to water pollution Assessment of Marine Litter in Coastal and Marine Environment of Western and Southern, (November).

[13] Yong Chang Jang, K. N. U., R R M K P Ranatunga, J. Y. M., \& Kyung Shin Kim, S. Y. H. (2011). “ Composition and abundance of marine debris stranded in beaches of Sri Lanka : Results from the first national survey," 172. 